\title{
Effect of Dietary Fiber on Utilization of Energy and Protein in Chickens
}

\author{
Suthut Siri, Hisaya ToBioka and Iwao TASAKI \\ Department of Animal Science, School of Agriculture, \\ Kyushu Tokai University, Kumamoto 869-14.
}

\begin{abstract}
Cellulose powder, pectin, alginic acid and finely ground rice straw were used as the dietary fiber source. Experimental diets were composed of soybean protein, corn starch, cornoil and some minor ingredients with $10 \%$ of above mentioned dietary fibers. A total of 8 colostomized White Leghorn male chickens were forced-fed $70 \mathrm{~g} /$ day of the experimental diets for 7 days alternatively so as to make a $4 \times 4$ Latin-square design. The amount of fresh feces was significantly higher in the pectin and alginic acid diets, however, water content in the feces was also higher in these diets. Consequently, the dry matter excreted were not different between the treatments, which resulted in no difference of dry matter and energy digestibilities among the diets. Protein digestibility was higher in the cellulose diet and lower in the pectin diet due to the significant difference in fecal nitrogen excretion. Urinary nitrogen was very low in the cellulose diet, and reflecting it biological value of protein was higher in the cellulose diet. Acid detergent fiber was digested by chickens to a small extent, but hemicelluloses seemed to be not digested, because the digestibility of neutral detergent fiber was the same to that of acid detergent fiber.
\end{abstract}

(Jpn. Poult. Sci. 29 : 23-29, 1992)

Key words : dietary fiber, energy utilization, protein utilization, chicken

\section{Introduction}

Dietary fiber is defined as the plant polysaccharides and lignin which are resistant to hydrolysis by the digestive enzymes of $\operatorname{man}^{11}$. It has been reported that the dietary fiber reduces utilization of nutrients including protein in humans and $\operatorname{rats}^{2-4)}$. According to DeLORME and GoRDON ${ }^{5)}$, pectin lowered the digestibility of energy and protein in rats. KIBE et al. ${ }^{6)}$ reported that dietary cellulose slightly increased biological value and true digestibility of protein in chickens. The present experiment was carried out to compare the effects of some dietary fibers on utilization of energy and protein in chickens, since this kind of study was scanty.

\section{Materials and Methods}

Cellulose powder, pectin, alginic acid and finely ground rice straw were used as the dietary fiber source. The composition of experimental diets was as follows (in \%) : soybean protein ( $90 \%$ protein) 21.4 , corn starch 61.6 , corn oil 1.0 , DL-methionine 0.15 , choline chloride 0.15 , vitamin mixture 0.07 , mineral mixture 5.63 , and either cellulose powder, pectin, alginic acid or finely ground rice straw 10.0. Where, vitamin mixture contained (mg/0.7 g) thiamin $\mathrm{HCl} \mathrm{100,} \mathrm{niacin} 100$, riboflavin 16 , inositol 100 , biotin 
0.6, Ca-pantothenate 20, vitamin $\mathrm{B}_{12} 0.02$, pyridoxine $\mathrm{HCl} 6$, folic acid 4, p-aminobenzoic acid 2, menadione 5, ascorbic acid 250, vitamin $A$ acetate $(1,000,000 \mathrm{IU} / \mathrm{g}) 10$, vitamin $\mathrm{D}_{3} 0.015$, vitamin $\mathrm{E} 0.0005$, BHT 0.0156 and made up to $0.7 \mathrm{~g}$ with corn starch. Mineral mixture contained $(\mathrm{g} / 56.3 \mathrm{~g}) \mathrm{CaHPO}_{4} 20.7, \mathrm{CaCO}_{3} 14.8, \mathrm{KH}_{2} \mathrm{PO}_{4} 10.0, \mathrm{KCl} 1.0$, $\mathrm{NaCl} 6.0, \mathrm{FeSO}_{4} \cdot \mathrm{H}_{2} \mathrm{O} 0.333, \mathrm{MgSO}_{4} 3.0, \mathrm{MnSO}_{4} \cdot \mathrm{H}_{2} \mathrm{O} 0.333, \mathrm{CuSO}_{4} \cdot 5 \mathrm{H}_{2} \mathrm{O} 0.0167, \mathrm{KI}$ 0.0026, $\mathrm{ZnO} 0.062, \mathrm{CoCl} \cdot 6 \mathrm{H}_{2} \mathrm{O} 0.0017, \mathrm{Na}_{2} \mathrm{MoO}_{4} \cdot 2 \mathrm{H}_{2} \mathrm{O} 0.0083, \mathrm{Na}_{2} \mathrm{SeO}_{3} 0.0001$ and made up to $56.3 \mathrm{~g}$ with corn starch.

Twelve-month-old White Leghorn male chickens were colostomized by the method of OKUMURA ${ }^{7)}$, and 8 of which were taken as experimental animals based on the health condition. They were divided into 4 groups of 2 birds each and were forced-fed 70 $\mathrm{g} /$ day of the experimental diets for 7 days, of which last 3 days were employed for collection of feces and urine. The diets provided were changed every week to make a $4 \times 4$ Latin-square design. During the experimental period the birds were kept in individual metabolism cages which were placed in a room maintained at $21 \pm 2^{\circ} \mathrm{C}$, and lighting was provided for 24 hours continuously. Feces and urine were separately collected every day from artificial and original ana, respectively. Pooled feces thus collected were dried up using a forced air oven at $55^{\circ} \mathrm{C}$ for 72 hours, and ground for chemical analysis. Pooled urine was stored in a deep freezer till analysis.

Dry matter (DM) of the diets and feces was determined by the method of $\mathrm{AOAC}^{8)}$. Nitrogen of the diets, feces and urine was determined by Kjeldahl method, and energy by means of a bomb calorimeter (Shimadzu Co. CA-3). Acid detergent fiber (ADF) and neutral detergent fiber (NDF) in the diets and feces were determined by the methods of VAN SoEST ${ }^{9)}$, and VAN SoEST and WINE ${ }^{10)}$, respectively. True digestibility and biological value of protein were calculated using values of metabolic fecal nitrogen and endogenous urinary nitrogen which were obtained by Terapuntuwat and TASAKI ${ }^{11)}$, since they were not determined in this experiment. The data were subjected for statistical analysis, and the comparison of the treatment means was made by DunCan's New Multiple Range Test ${ }^{12)}$.

\section{Results and Discussion}

Intake and fecal excretion of DM and energy are shown in Table 1. The amounts of fresh feces varied remarkably; i.e., significantly higher in the pectin and alginic acid diets than in the cellulose and rice straw diets, however, the DM contents were also quite different, higher in the cellulose and rice straw diets. Consequently, the amounts of DM excreted into feces were not different between dietary treatments. As a result, DM digestibility was not different between the diets used here. The chickens fed the pectin or alginic acid diet excreted more water in the feces due to high water holding capacity of pectin and alginic acid. TSAI et al. ${ }^{13)}$ reported that the rats fed a diet containing pectin showed mild diarrhea, but appeared normal and healthy. WAGNER and THOMAS ${ }^{14)}$ reported that the chicks fed a pectin diet excreted sticky feces.

The fecal energy excretion was not different between dietary treatments, and consequently energy digestibility was not different between them, being about $88 \%$. This result was supported by АкiвA and Matsumoto ${ }^{15)}$, who reported that the 
Table 1. Fecal excretion and digestibility of DM and energy

\begin{tabular}{lllrrrrr}
\hline \hline \multicolumn{1}{c}{ Diet } & & & Cellulose & Pectin & $\begin{array}{c}\text { Alginic } \\
\text { acid }\end{array}$ & $\begin{array}{c}\text { Rice } \\
\text { straw }\end{array}$ & SEM \\
\hline \multirow{2}{*}{ Intake } & DM & (g/day) & 62.2 & 62.0 & 61.7 & 61.9 & \\
& Energy & (kcal/day) & 277.5 & 274.7 & 269.6 & 280.5 & \\
\hline \multirow{4}{*}{ Feces } & Fresh & $(\mathrm{g} /$ day $)$ & $46.1^{\mathrm{a}}$ & $96.2^{\mathrm{b}}$ & $84.3^{\mathrm{b}}$ & $54.0^{\mathrm{a}}$ & 4.5 \\
& $\mathrm{DM}$ & $(\%)$ & $20.5^{\mathrm{b}}$ & $9.1^{\mathrm{a}}$ & $11.2^{\mathrm{a}}$ & $17.1^{\mathrm{b}}$ & 1.1 \\
& $\mathrm{DM}$ & $(\mathrm{g} /$ day $)$ & 9.4 & 8.6 & 9.9 & 9.0 & 0.7 \\
& Energy & $(\mathrm{kcal} /$ day $)$ & 34.7 & 31.8 & 31.1 & 33.1 & 2.6 \\
\hline \multirow{2}{*}{$\begin{array}{c}\text { Digestibility } \\
(\%)\end{array}$} & DM & & 84.9 & 86.1 & 84.0 & 85.0 & 1.1 \\
& Energy & & 87.5 & 88.4 & 88.5 & 88.2 & 0.9 \\
\hline
\end{tabular}

Means not sharing a common superscript letter are significantly different $(\mathrm{P}<0.05)$.

Table 2. Digestibility and biological value of protein

\begin{tabular}{llccccc}
\hline \hline \multicolumn{1}{c}{ Diet } & & Cellulose & Pectin & $\begin{array}{c}\text { Alginic } \\
\text { acid }\end{array}$ & $\begin{array}{c}\text { Rice } \\
\text { straw }\end{array}$ & SEM \\
\hline Nitrogen intake & (g/day) & 2.13 & 2.16 & 2.16 & 2.23 & \\
Fecal nitrogen & (g/day) & $0.13^{\mathrm{a}}$ & $0.38^{\mathrm{c}}$ & $0.23^{\mathrm{b}}$ & $0.20^{\mathrm{b}}$ & 0.02 \\
Urinary nitrogen & (g/day) & $0.57^{\mathrm{a}}$ & $1.04^{\mathrm{b}}$ & $1.14^{\mathrm{b}}$ & $1.09^{\mathrm{b}}$ & 0.07 \\
True digestibility & $(\%)$ & $96.8^{\mathrm{c}}$ & $85.6^{\mathrm{a}}$ & $92.1^{\mathrm{b}}$ & $93.8^{\mathrm{b}}$ & 0.75 \\
Biological value & $(\%)$ & $90.0^{\mathrm{b}}$ & $63.2^{\mathrm{a}}$ & $60.7^{\mathrm{a}}$ & $64.1^{\mathrm{a}}$ & 3.61 \\
\hline
\end{tabular}

Means not sharing a common superscript letter are significantly different $(\mathrm{P}<0.05)$.

addition of cellulose, rice hull, rice hull NDF, alfalfa meal, peanut hull NDF and polyamide at a level of $4 \%$ did not change energy retention of forced-fed chicks. On the contrary, Viola et al. ${ }^{16)}$ reported that the dietary fiber, particularly pectin, reduced the digestibility of energy.

Digestibility and biological value of protein are indicated in Table 2. Fecal nitrogen excretion was highest in the pectin diet followed by the alginic acid and rice straw diets, and lowest in the cellulose diet $(\mathrm{P}<0.05)$. Urinary nitrogen excretion was not different between the pectin, alginic acid and rice straw diets, but that for the cellulose diet was significantly lower than that for the other diets. This result is in agreement with the reports by NomANi et al. ${ }^{17)}$ and SHAH et al. ${ }^{4)}$.

True digestibility of protein was consistently higher in the cellulose diet and lower in the pectin diet, but the difference between the highest and the lowest was not so large. VIOLA et al. ${ }^{16)}$ and FLEMING and $\operatorname{LEE}^{20)}$ also reported that the lowest protein digestibility was obtained in a pectin diet with rats. As discussed by Forman and SCHNEEMAN ${ }^{18)}$, pectin might coat the absorptive lining of the gut, thereby interfering with the absorption of the products of digestion. SHAH et al. ${ }^{21)}$ reported that pectin reduced the pepsin and trypsin activities, because pectin is water soluble fiber that gives rise to highly viscous solution or even gels when dissolved, thereby slowing transport phenomena such as diffusion and mixing, and increasing the size of the unstirred layer, and also pectin contains ionizable carboxylic acid groups that can act 
as the ion-exchangers. The above mechanisms can serve to explain why pectin reduces protein digestibility. As stated before dietary pectin increased fecal nitrogen excretion. Such an increased fecal nitrogen loss may partially be due to the increased secretion of digestive enzymes as discussed by Forman and Schneeman ${ }^{18)}$. Sheard and SCHNEEMAN ${ }^{19)}$ suggested the possibility that pectin might increase the sloughing of cells of intestinal mucosa. If so, metabolic fecal nitrogen would be more than estimated, and the digestibility of protein of the pectin diet might be higher than that shown in Table 2.

The biological value of protein was higher in the cellulose diet than in the other diets, and the difference was almost $30 \%$. This figure is very similar to the result of Nomani et al. ${ }^{17)}$. The high biological value of the cellulose diet was due to the low excretion of urinary nitrogen, however, the reason why dietary cellulose reduced urinary nitrogen excretion was not clarified yet.

NDF and ADF contents of the ingredients of diets are indicated in Table 3. Corn starch and soybean protein did not contain NDF and ADF. Cellulose powder contained $95 \%$ of $\mathrm{NDF}$, of which $93 \%$ was $\mathrm{ADF}$, and rice straw contained $70 \%$ of $\mathrm{NDF}$, of which $70 \%$ was ADF. According to the definition of dietary fiber, pectin and alginic acid might not contain NDF and ADF. In fact, NDF was not detected in both alginic acid and pectin, but by the usual method for ADF determination a quite big ADF value was obtained particularly in alginic acid, because alginic acid is acidprecipitable.

Intake and fecal excretion of NDF and ADF in the experimental birds fed the cellulose and rice straw diets are shown in Table 4 together with the digestibility of these substances. NDF intake was a little higher than ADF intake because the diets

Table 3. Contents of ADF and NDF in ingredients of the diet $(\%)$

\begin{tabular}{lcc}
\hline \hline & NDF & ADF \\
\hline Soybean protein & 0 & 0 \\
Corn starch & 0 & 0 \\
Cellulose powder & 94.71 & 88.25 \\
Rice straw & 69.74 & 49.08 \\
\hline
\end{tabular}

Table 4. Digestibility of ADF and NDF (mean \pm SE)

\begin{tabular}{llcc}
\hline \hline \multirow{2}{*}{ Intake (g/day) } & & NDF & ADF \\
& Cellulose diet & 6.63 & 6.18 \\
& Rice straw diet & 4.88 & 3.44 \\
\hline \multirow{2}{*}{ Fecal excretion (g/day) } & Cellulose diet & $6.08 \pm 0.15$ & $5.47 \pm 0.13$ \\
& Rice straw diet & $3.50 \pm 0.33$ & $2.47 \pm 0.23$ \\
\hline \multirow{2}{*}{ Digestibility (\%) } & Cellulose diet & $8.26 \pm 2.26$ & $11.47 \pm 2.13$ \\
& Rice straw diet & $28.30 \pm 6.82^{*}$ & $28.02 \pm 6.67^{*}$ \\
\hline
\end{tabular}

${ }^{*}$ Significantly different $(\mathrm{P}<0.05)$ between diets. 
contained higher NDF than ADF as shown in Table 3. Fecal excretion also followed this tendency, and the digestibility of NDF was not statistically different from that of $\mathrm{ADF}$ both in the cellulose and rice straw diets. Most part of $\mathrm{ADF}$ is recognized to be cellulose, and the part of NDF other than ADF is mainly hemicelluloses. The statistical data also showed that the digestibility of ADF and NDF were significant. It means that the birds can digest cellulose even if a very small amount, but can not digest hemicelluloses, however, the amount of hemicellulose intake was very small, and more precise experiment will be needed to verify whether hemicellulose can not be digested. The fiber digestibility of the rice straw diet was almost 3 folds that of the cellulose diet, and the difference was quite significant. It seems that the fiber of rice straw is more easily digested by the chicken than the cellulose powder used in this experiment.

In conclusion, cellulose powder, pectin, alginic acid or rice straw do not affect the digestibility of dry matter or energy of the diets, but the dietary pectin reduces protein digestibility of the diet. Biological value of protein is remarkably improved by the addition of cellulose. Possibility is shown that a part of cellulose can be digested by the chicken.

\section{References}

1) Spiller, G.A. (1986) Definition of Dietary Fiber, pp. 15-18. In: Handbook of Dietary Fiber in Human Nutrition, (SPIller, G.A. ed.) CRC Press, Boca Raton, Florida.

2) Reinhold, J.G., B. Faradji, P. Abadi and F. Ismail-Beigi (1976) Decreased absorption of calcium, magnesium, zinc and phosphorus by humans due to increased fiber and phosphorus consumption as wheat bread, J. Nutr., 106 : 493-503.

3) Harmuth-Hoene, A.E. and R. Schelenz (1980) Effect of dietary fiber on mineral absorption in growing rats, J. Nutr., $110: 1774-1784$.

4) Shah, N., M.T. Atallah, R.R. Mahoney and P.L. Pellett (1982) Effect of dietary fiber components on fecal nitrogen excretion and protein utilization in growing rats, J. Nutr., 112 : 658-666.

5) Delorme, C.B. and C.I. Gordon (1983) The effect of pectin on the utilization of marginal levels of dietary protein by weanling rats, J. Nutr., $113: 2432-2441$.

6) Kibe, K., I. TASAKI and M. Saito (1964) Effects of fiber on the biological value and true digestibility of dietary protein and on the development of internal organs of chicks, Jpn. J. Zootech. Sci., 35 : 159-166.

7) Okumura, J. (1976) Method of colostomy and cannulation in the chickens, Br. Poult. Sci., $17: 574-551$.

8) AOAC (1984) Official Methods of Analysis, 14 th ed., AOAC Inc., Arlington.

9) VAN SoEst, P.J. (1963) The use of detergents in the analysis of fibrous feed. II. A rapid method for the determination of fiber and lignin, J. AOAC, 46:829-835.

10) Van Soest, P.J. and R.H. Wine (1967) Use of detergent in the analysis of fibrous feed. IV. Determination of plant cell-wall constituents, J. AOAC, 50 : 50-55.

11) Terapuntuwat, S. and I. Tasaki (1984) Protein and amino acid digestibility, biological value of protein and energy metabolizability of some leaf protein concentrates in chickens, Jpn. Poult. Sci., $21: 64-73$.

12) Steel, R.G.D. and J.H. Torrie (1980) Principles and Procedures of Statistics, 2nd ed., McGraw-Hill Book Co., New York, pp. 187-188.

13) Tsai, A.C., J. Elias, J.J. Kelley, R.C. Lin and J.R.K. Robson (1976) Influence of certain dietary fibers on serum and tissue cholesterol levels in rats, J. Nutr., 106 : 118-123. 
14) Wagner, D.D. and O.P. Thomas (1977) A rye type growth depression of chicks fed pectin, Poult. Sci., 56 : 615-619.

15) Akiba, Y. and T. Matsumoto (1980) Effects of several types of dietary fibers on lipid content in liver and plasma, nutrient retentions and plasma transaminase activities in force-fed growing chicks, J. Nutr., 110 : 1112-1121.

16) Viola, S., G. Zimmermann and S. Mokady (1970) Effect of pectin and algin upon protein utilization, digestibility of nutrients and energy in young rats, Nutr. Rep. Int., $1: 367-375$.

17) Nomani, K.Z.A., E.F. Fashandi, G.K. Davis and C.J. Bradac (1979) Influence of dietary fiber on the growth and protein metabolism of the rat, J. Food Sci., 44: 745-751.

18) Forman, L.P. and B.O. Schneeman (1980) Effects of dietary pectin and fat on the small intestinal contents and exocrine pancreas of rats, J. Nutr., 110 : 1992-1999.

19) Sheard, N.F. and B.O. Schneeman (1980) Wheat bran's effect on digestive enzyme activity and bile acid levels in rats, J. Food Sci., $45:$ 1645-1648.

20) Fleming, S.E. and B. Lee (1983) Growth performance and intestinal transit time of rats fed purified and natural dietary fibers, J. Nutr., 113 : 592-601.

21) Shah, N., R.R. Mahoney and P.L. Pellett (1986) Effect of guar gum, lignin and pectin on proteolytic enzume levels in the gastrointestinal tract of the rat: A time based study, J. Nutr., 116 : 786-794. 


\title{
鶏におけるエネルギーおよび蛋白質の利用性に 対する食物繊維の影響
}

\author{
Suthut SIRI ・飛岡久弥・田先威和夫 \\ 九州東海大学農学部畜産学科, 熊本 869-14
}

本実験においては，市販の大豆蛋白を蛋白質源とし， 食物繊維としてセルロース末，ペクチン，アルギン酸ま たは細粉稲ワラを各 $10 \%$ 含む半精製飼料を人工肍門設 着鶏に定量給与し，霬および尿を採取して上記食物瀻維 が飼料のエネルギーおよび蛋白質の利用性に及ぼす影響 を中心に検討した。

各飼料を同量給与したにもかかわらずペクチンおよび アルギン酸給与鵎では排䔬量が特に多かったが，これは ペクチンおよびアルギン酸の保水性が高く，そのために 糞中水分含量が多くなったためであり，乾物排泄量では 各飼料間に有意差がみられなかった。すなわち乾物消化 率に対する食物瀻維の影響はなかった。またエネルギー の消化率についても飼料間差はなかった。

糞中窒素排泄量はペクチン給与で有意に多く，七ルロ 一ス給与で有意に少なかった。これを反映して蛋白質の 消化率はセルロース給与で有意に高く，ペクチン給与で 有意に低かった。なお蛋白質の生物価はセルロース給与 により他よりあ高い值を示したが，これはセルロース給 与時の尿中排泄窒素量が特に少なかったことに起因して いる。しかしこのような現象の生じた理由については明
らかにできなかった。

本実験に用いたセルロース末は約 $95 \%$ の NF を含 み,このうち $88 \%$ が ADF で, 稲ワラは NDF が 70 $\%, \mathrm{ADF}$ が $50 \%$ であった。 NDF のうち ADF 以外 の部分はへミセルロースと考えられるが，この含有割合 はセルロース末では非常に少なく，稲ワラでは $20 \%$ に あ達していた。NDFと ADF の損取量と排泄量から それらの消化率を計算すると，いずれあ稲ワラのほうが セルロース末よりあ有意に高く，また両者とも有意な消 化率を示した。すなわち通常の飼育条件では，僅かでは あるが鵎はセルロースを消化でき，さらに稲ワラのセル ロースは，ここに用いた純セルロース末よりあ消化性が 高いと考えられる。しかし前述したようにエネルギーの 消化性に差がみられないことから，見掛上の消化性が高 まっても，真に利用性が向上したとは考えにくい。なお $\mathrm{ADF}$ とDF の消化率に差がないことは, へミセル ロースの消化性がないことを意味している。

（家禽会誌，29：23-29，1992）

キーワード: 食物繊維, エネルギー利用性, 蛋白質利用 性, 鶏 